\title{
KunstKammers AND Museums
}

\author{
Mogens Bencard
}

The value and importance of the exhibition 'Museum Europa' and the accompanying collection of essays published in 'Den Jyske Historiker' lies in the fact that they look at the museum in a new way. Points have been raised which will be fruitful in the discussion of the idea of the museum and its role in the past as well as in the future. Many of the contributors to the essay collection come from fields contiguous to those of the normal museum employee. This introduces new discussions and also a new language, not always, I must confess, easy to read, but always interesting.

This paper will try to examine one aspect of this discussion, namely the role of the Kunstkammer, and the way the Kunstkammer has been treated, or rather overlooked as a museum.

According to the essayists, who touch on this, the oldest museum is the Ashmolean Museum in Oxford, and apart from that no museums seem to have existed before the French Revolution. If I have interpreted this correctly, I must lack a definition of what a museum really is. Surely, Elias Ashmole's collections did not become a museum, just because it was handed over to a body of learned Oxford dons? And surely, the former royal or princely Kunstkammers did not become museums, just because the political system changed from "l'état, c'est moi" to "l'état, c'est nous"? This is the only definition of a museum I can deduce from this seemingly generally accepted concept.

In 1833, when the Lord Marshall A.W.Hauch organized a new museum system on the basis of the Danish Kunstkammer, he wrote to his still absolute, if very bourgeois, sovereign:

Thanks to Your Majesty's gracious protection of the Arts and Sciences I have succeeded in bringing the Royal Collections in such an order that they can be of use to artists and scientists, and, due to their purposeful arrangement, can be counted among the Nation's embellishments and sights.

I do not think that in using these words Hauch made a distinction between the new museums and the old Kunstkammer. He saw the change as a positive development. Over the years the Danish Kunstkammer had become overcrowded, filled with objects within a space, that had not changed. In other words useless to a public wanting to be educated rather than go treasure-hunting.

Hauch's words provide a definition, which gives museums a place in the nation's 
MOGENS BENCARD

22 educational system and a role in the expression of national pride. It establishes them as part of the national identity, to use a modern terminology. In my opinion this remains a basic definition of the modern museum, and, as far as I can see, also a basic definition of the Kunstkammer.

To be educational a collection must of course be accessible to the public, be it select or general. And also, it must in its actual collecting be systematic in accordance with an idea.

Museum Europa shows how "the curious eye" - the open-mindedness - of the 16th and 17 th centuries collected in order to obtain a comprehensive view of the world - a microcosm. But also that the Kunstkammer was systematic in its arrangement of chambers so as to contain all the specialized museums of the modern world: the museum of the Natural Sciences, the museum of History, the Armoury, the Art Gallery, The Print Room, the museum of Decorative Arts, the Coin collection, and the Ethnographical museum.

In order to demonstrate that this search for comprehensiveness was not just official state policy (and not just the savant's in his private study) I have chosen two small, partly preserved, collections made by members of the Danish royal family. One is a cabinet of curiosities, a Kunstschrank, which belonged to Queen Charlotte Amalie (1650-1714), and the other a collection made by her son, King Frederik IV (1671-1730), contained in a number of wall-cupboards in Rosenborg Palace.

Queen Charlotte Amalie was a keen collector - of land as well as of porcelain, of moors and monkeys, dwarfs and Norwegian boys (Laps?).

Her Kunstschrank is a beautiful black cabinet, made in Japan. Its gilt-wood stand was carved in Copenhagen with her coat-of-arms. Behind the doors are ten drawers which contained almost a thousand shells, and seventeen other items.

The shells themselves have disappeared, but were listed in 1775 in such detail that it has been possible to identify each species. Their provenance covers practically all corners of the world.

Of the other items six are Naturalia, one Artificialia, and the rest are Ethnographica. Among the latter two "Indian" drawings may of course have been thought to cover the Fine Arts, and a box of "Indian" coins the Coin Cabinet. In other words these items may have been chosen to represent most of the categories within the Kunstkammer.

This leads to the following conclusions:

1. that the Queen even in this small cabinet had collected according to the terms of the Kunstkammer, i.e. to create a geographical as well as a thematic microcosm.

2. the items preserved can only barely be fitted into the one drawer which contained them. The great number of shells must have been tightly packed into their drawers.

3. the collection was not decoratively arranged in the cabinet, but must have been kept with more serious intentions. No individual shell or item could be studied without being lifted out of its cramped dwelling.

Thus the Queen's small collection may be understood as having had an educational value - if only for the Queen herself and a close circle around her.

King Frederik IV's collection in the 
Queen Charlotte Amalie's Kunstschrank. End of 17 th century. Japanese cabinet on a wooden stand, carved in Cophenhagen. Photo: Lennart Larsen.

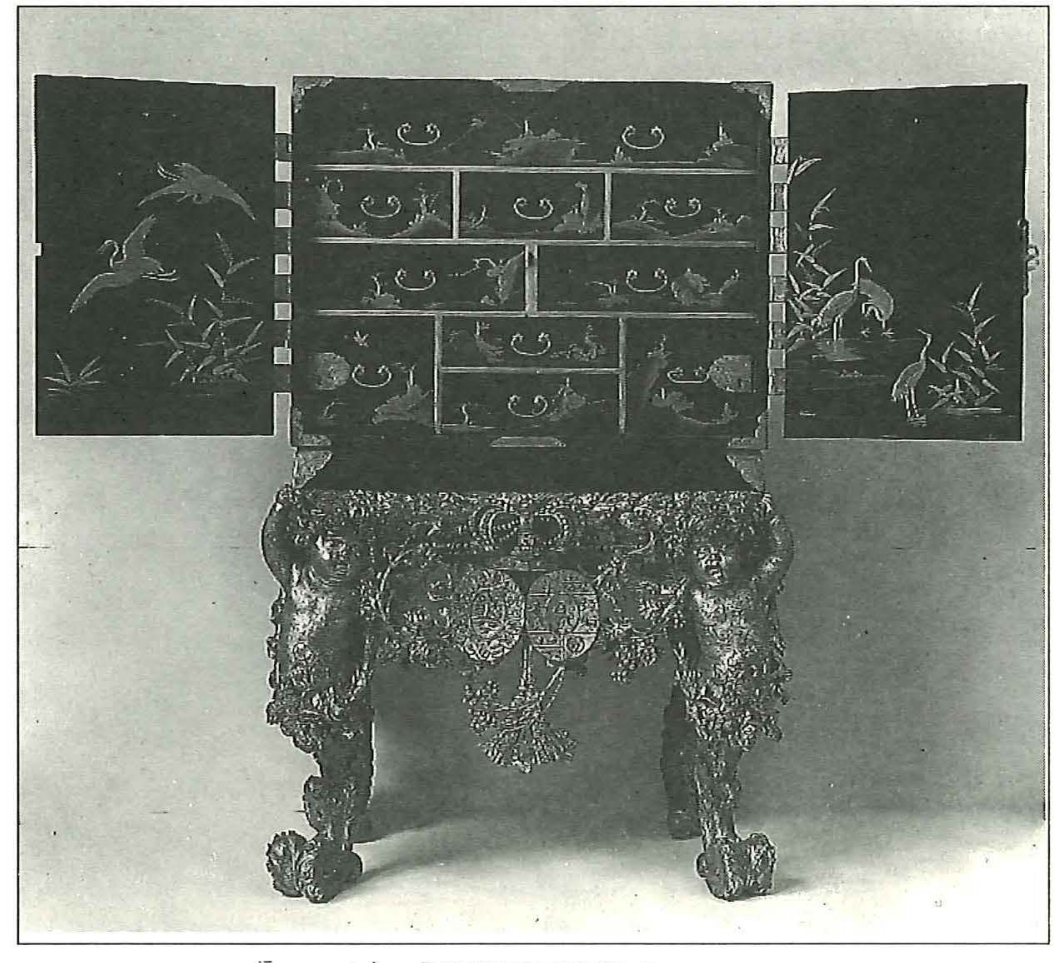

Winter Room at Rosenborg, was created around 1715 and listed in 1718. It was contained in five cupboards, installed behind the 17th century panelling of the room. Decorative festoons in the cupboards demonstrate that the items, placed on shelves, were not just stored away, but were arranged to appear as a display, when the doors were opened.

The items were removed in 1749 , but are partly preserved in other museums. They can be placed into the categories of the Kunstkammer as being Artificialia, Naturalia, Ethnographica, Technicalia, and - surprisingly, considering the normally closed doors - even the Fine Arts. The total number of items amounted to ca 500 pieces, of which the majority are Artificialia.

In conclusion once again, and this time much more obviously, one finds the comprehensive ideals of the Kunstkammer, a private collection of carefully and systematically chosen objects, which constitute a microcosm, the king's private teatrum mundi.

Like his mother, Frederik IV was a keen collector. In 1714 he had arranged his glass collection at Rosenborg in the still preserved Glass Cabinet. The so-called Green Cabinet in the same palace contained a collection of Pretiosa - a Schatzkammer so private that only the king himself had the keys to it. Furthermore he had ordered a Porcelain Cabinet, but this never materialized.

These types of cabinets, which became so popular in European residences around 1700 , were created to display only one 
MOGENS BENCARD

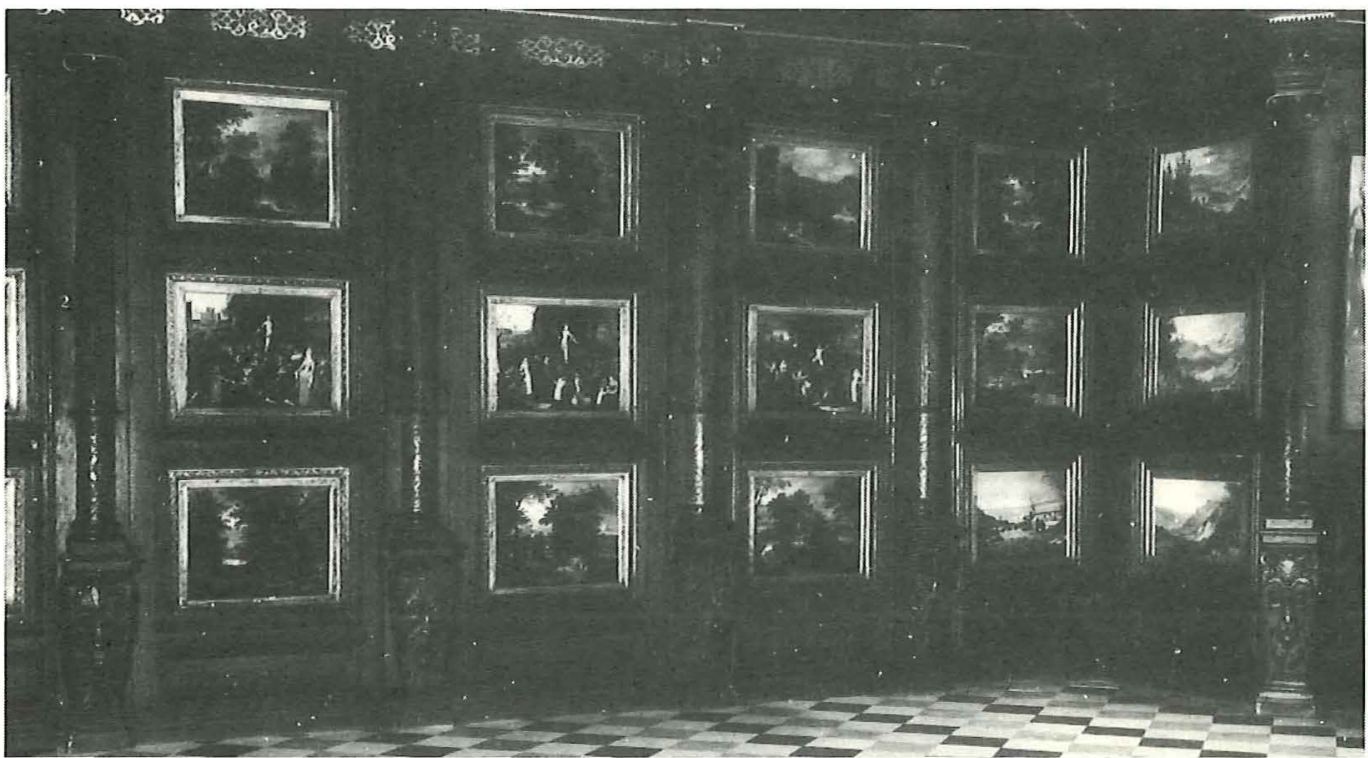

The Winter Room at Rosenborg. 1617. Behind the panelling are cupboards, in which Frederik IV installed his private Kunstkammer. Photo: Lennart Larsen.

group of items, usually porcelain. They contrast strongly with the basic ideas of the Kunstkammer, the exhibition of Nature's and Man's creations. These ideas are clearly stated in the case of Frederik IV's Winter Room cupboards, and only sketched in the case of Charlotte Amalia's cabinet. One can, however, see that there were systematic principles, not just haphazardous individual fancies behind their collecting. In this respect they do not differ from a modern museum.

Apart from his small private Kunstkammer, King Frederik had the official Kunstkammer to bear witness to his own and of course his people's - prestige. When the Kunstkammer building was finished by his father in the 1670's, it was opened to the public. This was also the case with most of the other European Kunstkammers. The educational purpose of the Kunstkammer was underlined by
Peter the Great, when his Kunstkammer was opened in 1714 in St. Petersburg. "I want people to look and learn", he declared.

So, if my definition of a museum as an educational institution, and a basis for national prestige is acceptable, I cannot see, that there is much difference between it and the Kunstkammer.

Of course, the French Revolution opened the museums to a more general public than the more limited circles - including travelling noblemen and scholars - allowed into the Kunstkammers. But is this sufficient grounds for a differentation between the two?

Mogens Bencard er mag.art i kunsthistorie, 1961-77 antikvar ved Den antikvariske Samling $i$ Ribe, 1977-80 prosjektleder for Sydjysk Universitetscenter, Esbjerg. Fra 1980 direktor for De Danske Kongers Kronologiske Samling på Rosenborg og Amalienborg. Adr: De Danske Kongers Kronologiske Samling på Rosenborg, Øster Voldgade 4A, DK-1350 Kobenhavn K). 